\title{
Inflation Dynamics in Sri Lanka: An Empirical Analysis
}

\author{
Sanduni Kulatunge
}

\begin{abstract}
This paper examines the dynamics of inflation in Sri Lanka using the cointegration approach on quarterly time series data. Considering recent empirical studies in the context of inflation in emerging countries including Sri Lanka, an empirical model has been constructed with seven variables; namely inflation, economic growth, government expenditure, exchange rate, money supply, oil prices and interest rates.

The main determinants of inflation in Sri Lanka are the economic growth, exchange rate, government expenditure, money supply, oil prices and interest rates in the long run. According to the estimated impulse response functions, both domestic shocks (money supply, interest rate and economic growth) and external shocks (exchange rate and oil prices) have an effect on inflation in the short run. These findings would be useful for policy makers in their effort in maintaining price stability in Sri Lanka on a sustainable basis.
\end{abstract}

\footnotetext{
Key Words: Inflation, Money Supply, Co-integration, Error Correction Model

JEL Classification: E31, E51, E52
}

\footnotetext{
${ }^{1}$ The author wishes to thank Prof. Kerry Patterson of University of Reading, UK and Dr. Susantha Liyanaarachchi of University of Griffith, Australia for their guidance and advice. The author is also thankful to Dr. Anil Perera, Mrs. Erandi Liyanage, Mrs. Amali Priyashanthi, Mrs. Tharaka Hansi, Miss Tehani Fernando and Mrs. Maheshi Perera of Central Bank of Sri Lanka for the encouragement, support and valuable comments. The author is also thankful to anonymous reviewers. Email: sanduni@cbsl.lk.
} 


\section{Introduction}

Inflation is an important macroeconomic variable. It can be defined as a sustained rise in the general level of prices i.e. a persistent rise in the price levels of commodities and services, leading to a fall in the currency's purchasing power. Low inflation environment provides a better environment for economic growth, encourages investors, employment opportunities and higher living standards. It is widely accepted that the pursuit of price stability is primary to long-run growth and development and should be the concern of every economy (Mallik, 2001; Kihangire, 2005; Odusunya and AbdulMalic, 2010; Bashir et al., 2011; Bhattacharya, 2013). Higher inflation causes adverse impacts on the economic performance of countries in many aspects and hence, the identification of determinants of inflation is very important.

Inflation reduces real value of money and tends to deteriorate the purchasing power parity of money in the country. In particular, higher inflation weakens export competitiveness and discourages exporters. According to Sahaduhhen (2012), unpredicted running and galloping inflation are regarded as unprecedented effects on an economy because they distort and disrupt the price mechanism, discourage investment and saving, adversely affect fixed income groups and creditors and ultimately leads to the breakdown of morals.

The stabilisation of the general price level has become a major macroeconomic objective of the monetary authorities in many other countries including Sri Lanka (Colombage, 2005). An analysis of the economic history reveals that inflation has been a major issue for policy makers in Sri Lanka. Table 1 provides a comparison of inflation rates in Sri Lanka with other economies and illustrates that except for Sri Lanka and emerging market and developing economies, all other regions maintain their inflation at low levels.

Table 1: Sri Lanka and World Inflation (Annual Average \% Change)

\begin{tabular}{|c|c|c|c|c|c|}
\hline Country & 1980 & 1990 & 2000 & 2010 & 2013 \\
\hline Sri Lanka & 26.1 & 21.5 & 6.2 & 6.2 & 6.9 \\
\hline World & 17.9 & 27.7 & 4.6 & 3.6 & 3.8 \\
\hline Advanced economies & 13.7 & 5.1 & 2.3 & 1.5 & 1.4 \\
\hline Euro area & $\mathrm{n} / \mathrm{a}$ & $\mathrm{n} / \mathrm{a}$ & 2.2 & 1.6 & 1.5 \\
\hline Major advanced economies (G7) & 12.4 & 4.7 & 2.2 & 1.4 & 1.3 \\
\hline European Union & 12.6 & 27.5 & 3.1 & 2.0 & 1.7 \\
\hline $\begin{array}{l}\text { Emerging market and developing } \\
\text { economies }\end{array}$ & $\mathrm{n} / \mathrm{a}$ & 98.7 & 8.6 & 5.9 & 6.2 \\
\hline Developing Asia & $\mathrm{n} / \mathrm{a}$ & 7.7 & 1.9 & 5.3 & 5.0 \\
\hline ASEAN-5 & 17.4 & 9.2 & 2.8 & 4.4 & 4.9 \\
\hline
\end{tabular}


Maintaining economic and price stability are core objectives of modern central bank practices. Similarly, maintaining low inflation has become a major objective of the government and the Central Bank of Sri Lanka (CBSL). Therefore, investigating the effect of key macroeconomic variables on inflation is vital for policy makers in the pursuit of their efforts to maintain macroeconomic stability.

Sri Lanka suffered from approximately 30 years of internal conflict only ended in 2009, which arguably is a major obstacle for the country's economic growth. Currently, Sri Lanka's economy is facing two challenges in terms of the high economic growth which commenced since the end of the internal conflict and the need to maintain macroeconomic stability to create the conditions for economic growth. Hence, maintaining a low inflation level has become important for Sri Lanka especially after the ending of the internal conflict. In particular, as Ratnasiri (2009) aptly claims, the identification of determinants of inflation and forecasting remain vital for economic agents. Therefore, it is essential to identify the main causes of inflation in Sri Lanka in order to adopt more viable economic policies. This study therefore is timely, as identifying the dynamics of inflation in Sri Lanka is essential especially for policy making purposes.

Similar to other developing countries, Sri Lanka has experienced a high inflation level during the last few decades. Considering the importance, several attempts have been made to explore determinants of inflation in Sri Lanka. For example, Weerasekara (1992) using causality tests, variance decompositions and impulse response functions identifies that the main source of inflation is the money supply in Sri Lanka. Meanwhile, Ratnasiri (2009) examines determinants of inflation in Sri Lanka by concentrating on economic factors and proves that both the demand side and supply side factors affected inflation in Sri Lanka. According to the findings of Cooray (2008), there is a long run relationship between price level, real GNP, exchange rate and import prices, exemplifying that supply side factors are the most important determinants of inflation in Sri Lanka. Bandara (2011) also investigates the determinants of inflation in Sri Lanka from 1993-2008, a period which was characterised by upward and downward trends in the economy. This study reveals that money supply, exchange rate and GDP contain information which helps in exploring the behaviour of inflation in Sri Lanka. Thus it is evident that these attempts are important in understanding the behaviour of inflation in Sri Lanka.

The present study, however, differs from the existing literature in the following ways. First, probing into determinants of inflation requires an explicit examination of the most relevant set of variables. Considering this, the study attempts to examine main determinants of inflation in Sri Lanka using a set of variables such as the government expenditure, money supply, GDP, interest rates, oil prices and exchange rate. ${ }^{2}$ To that end, this study would

\footnotetext{
2 Ratnasiri (2009) investigates determinants of inflation using variables of output gap, money supply, rice price, interest rate and exchange rate depreciation. However, the study does not consider dynamic interaction between inflation and fiscal variables.
} 
contribute to the available literature on inflation by focusing on the relationship of inflation with real, external, monetary and fiscal sectors of the economy, since a limited numbers of studies investigate the overall impact of macroeconomic aggregates on inflation, which is helpful for better economic policies. Second, with the consideration of the government expenditure, this study investigates the fiscal impact on expenditure, which plays a vital role in an economy. In particular, existing studies on inflation in Sri Lanka do not consider the effects of government expenditure on inflation, a gap that will be filled through this study. Third, this study identifies how oil price changes impact inflation, since most of the previous researchers in this area have not considered the effect of oil price changes on inflation in Sri Lanka. As Sri Lanka is a net importer of oil, Sri Lanka is vulnerable to spikes in international oil prices. ${ }^{3}$ Temporary shocks such as a raise in international oil prices and other commodity shocks have been dominant inflationary triggers (Goyal, 2011). Finally, the existing literature has identified there are several types of relationships (such as positive, negative, no correlation and threshold value) between inflation and other variables. Therefore identifying such kind of relationships would be important for economic policies. Hence, the findings of this study would have several important implications for policy makers such as monetary and fiscal authorities not only for Sri Lanka, but also for respective authorities in other emerging/developing economies.

Although there are several studies on inflation dynamics in Sri Lanka, there is scope for a fresh look at the determinants of inflation. Ratnasiri (2009) carried a VAR base analysis to identify the determinants of inflation in Sri Lanka, covering the period of 1980-2005 only. Thus this paper attempts to investigate the dynamics of inflation in Sri Lanka for the period of 2000Q1 to 2013Q4. Moreover, Sri Lanka could maintain inflation at a single digit level during last six years since 2009 especially after the ending of the internal conflict. Hence, identifying the determinants of inflation during a low inflation period would be useful for policy makers in their effort in maintaining price stability in Sri Lanka. Thus, it is evident that Sri Lanka's economy has undergone a significant structural change after 2009. After the ending of the internal conflict, the economy of Sri Lanka has displayed its true potential. While appropriate demand management policies are required to maintain low and stable inflation, effective addressing of supply-side impediments is also needed (CBSL, 2010). Hence, policy makers should continue to adopt appropriate policy measures to maintain inflation at low single digit level. Accordingly, identifying methods for the investigation of the overall impact of macroeconomic aggregates on inflation would be needed in order to sustain domestic price stability in a dynamic economic environment.

The remainder of the paper is structured as follows; Section 2 provides detailed background information, while Section 3 presents the theoretical background and literature review of the

\footnotetext{
${ }^{3}$ Relevance of external factors on inflation can be gauged most notably by prices of energy, as Sri Lanka is a net importer of oil. External effects are thought to play an important role in small open economies (Kusper, 2012). Ratnasiri (2009) uses only exchange rate to capture the external impact on inflation.
} 
study explaining the different findings of previous research related to the determinants of inflation. In addition, this section highlights determinants of inflation with special reference to Sri Lanka. Section 4 explains the methodology, while Section 5 consists of empirical analysis and Section 6 presents the concluding remarks of the study, which summarise the empirical findings of the study and the policy implications.

\section{Inflation in Sri Lanka}

\subsection{Overview of Inflation in Sri Lanka}

Around 1950, Sri Lanka's inflation rate was relatively low and was lower than industrial and developing countries (Rupananda, 1994). Inflation, which is measured by the Colombo Consumers' Price Index (CCPI, 1952=100), was 0.07 per cent during the period of 1948-1956. Increase in the general price level remained low during this period mainly due to the maintenance of a fixed exchange rate regime since 1948, maintenance of price controls and slower rate of monetary expansion (CBSL, 1998). Table 2 and Figure 1 show annual percentage changes in inflation in Sri Lanka during the period of 1948-2014.

Table 2: Annual Average Inflation (1948-2014)

\begin{tabular}{lc}
\hline \multicolumn{1}{c}{ Period } & Inflation (\%) \\
\hline $\begin{array}{l}\text { 1948-1956 } \\
\text { Post independence open economy }\end{array}$ & 0.07 \\
\hline $\begin{array}{l}\text { 1956-1965 } \\
\text { Closed economy }\end{array}$ & 1.2 \\
\hline $\begin{array}{l}\text { 1965-1970 Semi open economy } \\
\text { 1970-1977 } \\
\text { Closed socialist economy }\end{array}$ & 4.0 \\
\hline $\begin{array}{l}\text { Since 1977-2014 } \\
\text { Open economy }\end{array}$ & 5.7 \\
\hline Source: Central Bank of Sri Lanka & 10.9 \\
\hline
\end{tabular}

CCPI inflation was relatively low during the period of 1956-1965 as well, averaging 1.2 per cent due to economic controls such as direct control on international trade and foreign exchange outflows (CBSL, 1998). On the other hand, the period of 1965-1970, inflation was moderately high (4.0 per cent) due to the increase in import prices and the devaluation of the rupee. However, the devaluation of the rupee resulted in increased exports during this period.

The period of 1970-1977 was characterised by import substitution restrictions under a protectionist framework, the highest trade restriction ever adopted in Sri Lanka. Inflation increased to the double digit level of 12.3 per cent for the first time in history in 1974 due to an oil price hike. Average inflation was around 5.7 per cent during this period. 
Consequently, after introducing open economy policies in 1977, the Sri Lankan economy was opened to the rest of the world by removing trade barriers and exchange controls. With the removal of import and exchange controls, imports began to gain greater significance in affecting prices (Cooray, 2008). Further, after liberalisation, there was a rapid increase in public investment. This resulted in a rapid growth in the money supply. According to Weerasekara (1992), there has been a rapid growth in the nominal money supply and continuous depreciation of the exchange rate after introducing trade liberalisation policies in 1977. All these reforms resulted in accelerating inflation. The depreciation of the rupee and abolishment of the dual exchange rate in 1977 caused an increase in import price. Essential food items such as wheat flour and bread prices were revised upward in 1980, 1981 and 1984. Public transport fares and kerosene prices also increased in 1980 and 1983. In addition, the government public investment programme, high government capital expenditure and high budget deficit fuelled higher inflation. As a result, between 1978 and 1984, year on year inflation was 15.9 per cent, recording the highest ever inflation rate of 26.1 per cent in 1980, since independence. However, inflation reduced significantly to 1.5 per cent in 1985 . This was the first instance that a single digit rate was achieved since 1977. Enhanced production of most agricultural crops as a consequence of favourable weather conditions, continued restrictive credit policies, lagged effect of non-expansionary fiscal policies as well as lower import prices were contributory factors towards the lower inflation (CBSL, 1985). However adverse weather conditions and the internal conflict of the country caused an acceleration in inflation to double digit level again in 1988 and 1989.

In 1990, inflation rose significantly up to 21.5 per cent due to the increase in fertiliser prices, exchange rate depreciation of the previous year, increase in fuel prices and the upward revision of paddy prices (CBSL, 1990). During the period of 1991-1993 inflation remained low compared with 1990, due to favourable weather condition and contactionary monetary policies, but stood at a double digit level. The reduction of domestic food production due to drought conditions, cutting back of the subsidy on wheat and higher energy prices caused increased inflation up to a double digit level in 1996 (CBSL, 1996). Annual average inflation increased up to 15.9 per cent in 1997 and reduced to 4.2 per cent in 1999 mainly due to fiscal discipline, prudent monetary management, low import prices and tariff structure. Again, higher international commodity prices, currency depreciation and supply shortages in the country caused increase in inflation up to 14 per cent in 2001. 
Figure 1: Annual Inflation in Sri Lanka

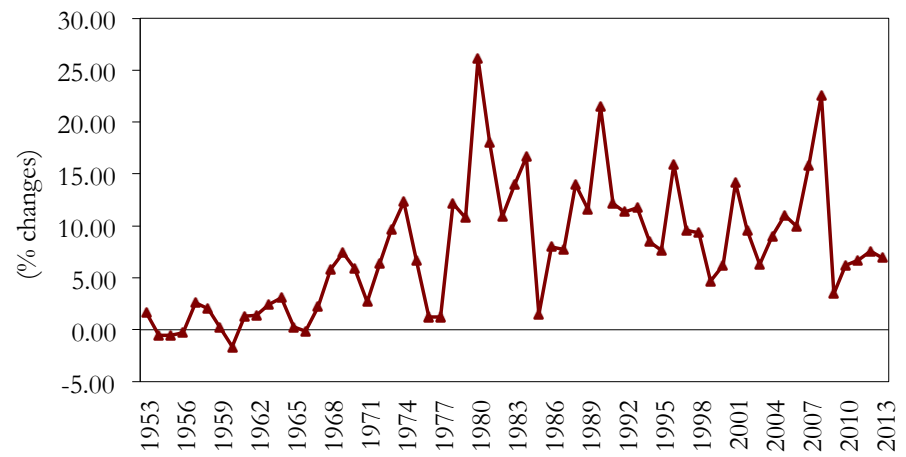

Sri Lanka experienced relatively low inflation in 2003 due to favourable domestic production and continued focus of monetary management on price stability. During this period, interest rates were reduced in order to stimulate the economy. However, international oil prices started to increase sharply from the end of 2004 and reached historically high levels in 2005, affecting oil importing countries like Sri Lanka adversely. In 2007 inflation increased by 17.5 per cent on year-on-year basis owing to continued escalation of global oil and gas prices, adverse developments of international commodity prices, reduction of domestic food production due to disturbance in major paddy production in the North and East due to terrorist activities and adverse weather conditions (CBSL, 2007).

By 2009 inflation reduced to single digit levels of 3.4 per cent, which was the lowest inflation recording in more than two decades. Both demand and supply side factors such as stringent monetary policy measures adopted by the CBSL, improved domestic supply conditions, decline in international commodity prices and stable exchange rate resulted in lower inflation during the year (CBSL, 2009). Inflation has continued to remain at a single digit level since then, recording 6.2 per cent, 6.7 per cent, 7.6 per cent, 6.9 per cent in 2010, 2011, 2012 and 2013 , respectively. Increase in domestic food supply, monetary policy measures adopted by the CBSL and downward tariff revisions to some consumer items caused low inflation in 2011, whereas improved supply conditions of agricultural production, downward revisions of some administered prices and duties on imported items and demand management strategies, together with managed inflation expectations, were the main drivers for low inflation in 2012 (CBSL, 2012). According to the CBSL (2013), prudent monetary management and improved domestic food supply led to a gradual decline in headline inflation, while core inflation was moderated to its lowest level by 2013, reflecting effective demand management policies and the lagged effect of the tight monetary policy stance in 2012. Due to the combined impact of prudent monetary management, relatively stable exchange rate, moderation in international commodity prices, fiscal policy measures taken 
towards addressing supply side disturbances and well managed inflation expectations by end 2014, year-on-year and annual average inflation were recorded at 2.1 per cent and 3.3 per cent, respectively (CBSL, 2014). Inflation on a year-on-year basis remained in the negative territory at -0.3 per cent for the third consecutive month in September 2015, supported by improved domestic supply conditions and subdued global commodity prices such as crude oil, dairy products, and wheat and maize.

It is observed that inflation has been significantly volatile in Sri Lanka and it was mainly determined by both demand side and supply side factors during the period of 1948-2013. It is essential to quantify the main sources of inflation in Sri Lanka, which may have caused such volatility in inflation in order to adopt better economic policies.

\subsection{Measures of Inflation in Sri Lanka}

Three major indicators such as CCPI, Wholesale Price Index (WPI) and Gross Domestic Product Deflator (GDPD) are used to measure changes in the general price level. The CCPI is the official cost of living index in Sri Lanka and currently 2006/2007 is taken as the base year. The CCPI is widely used by firms and individuals in planning current and future consumption and investment. It is compiled by the Department of Census and Statistics and is available on a monthly basis.

The CCPI covers a large number of commodities and is heavily weighted towards food items which comprise 41 per cent of the index. Housing, water, electricity, gas, and other fuels and transport items weighted 24 per cent and 12 per cent, respectively, in the commodity basket. The main categories of the commodity basket and their respective weights are shown in Table 3.4

The other available price indices are the WPI and the GDPD. These indices differ in terms of the goods and services included in the consumer basket, weights assigned to each item, geographic area of price collection, population coverage and the base year.

\footnotetext{
${ }^{4}$ Department of Census and Statistics is in the process of introducing a National Consumer Price Index (NCPI).
} 
Table 3: Colombo Consumers' Price Index: Weights by Main Categories

\begin{tabular}{lcc}
\hline \hline \multicolumn{1}{c}{ Category } & $\begin{array}{c}\text { CCPI Base } \\
\text { 2002=100 (\%) }\end{array}$ & $\begin{array}{c}\text { CCPI Base } \\
\text { 2006/07=100 (\%) }\end{array}$ \\
& & \\
\hline 1. Food and Non-alcoholic Beverages & 46.7 & 3.1 \\
2. Clothing and Footwear & 3.1 & 23.7 \\
3. Housing, Water, Electricity, Gas and Other fuels & 18.3 & 3.6 \\
4. Furnishing, Household Equipment and Routine Household & 3.2 & 3.2 \\
5. Heaintenance & 4.2 & 12.3 \\
6. Transport & 9.5 & 4.8 \\
8. Communication & 4.4 & 1.5 \\
9. Recreation and Culture & 2.2 & 3.9 \\
10. Education & 5.8 & 2.9 \\
11. Miscellaneous Goods and Services & 2.7 & 100.0 \\
\hline Total & 100.0 & \\
\hline
\end{tabular}

Source: Department of Census and Statistics

Broadly, there are two measures of measuring inflation, namely headline inflation and core inflation. Headline inflation refers to the rate of change in the overall price index. Factors like administrative price changes (electricity and transport), increase in imported prices (crude oil and sugar), adverse weather conditions (landslides, floods and drought), and seasonal demand due to New Year and Christmas influence headline inflation to exhibit some volatility. Core inflation reflects demand-pull inflation that responds to demand management policies. This captures the impact of underlying demand pressures. Inflation arising due to changes in food and energy prices is volatile and is often subject to temporary fluctuations caused by supply shocks, driven by weather disturbances or external shocks, and changes in administered prices or tax policies, which are beyond the control of the monetary authority. Core inflation excludes such volatile prices. In Sri Lanka core inflation is measured by excluding certain items such as fresh food, coconut nuts, rice, transport and fuel and energy, which are either highly volatile or administered prices.

Movements in Headline inflation and core inflation in Sri Lanka are presented below in Figure 2. In 2009, low levels of headline inflation were recorded compared to high core inflation. This low inflation was mainly attributed to favourable developments of the supply side factors such as decline in international commodity prices and revision of domestic administrative prices. Headline inflation was higher than the core inflation in 2012 due to the price increases of the non-food category, mainly on account of the upward price adjustment 
for fuel and bus fares. Low volatility in core inflation reflects that the demand driven inflationary pressure was well contained from mid 2013 till 2014.

Figure 2: Headline Inflation and Core Inflation

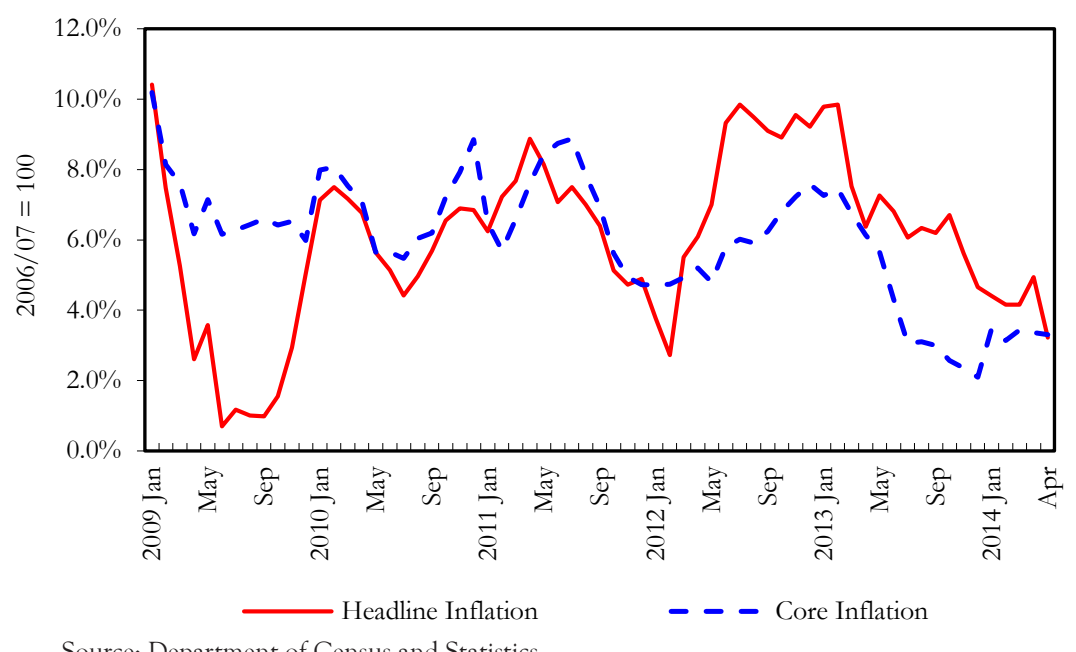

\section{Theoretical Background and Literature Review}

\subsection{Theoretical Background}

There are various theories of inflation in economic thought and numerous empirical studies have been conducted on the determinants of inflation. The relationship between inflation and its key determinants is an important building block in macroeconomic theory (Sahadudheen, 2012).

Most of the theories of inflation are formulated on the basis of demand pull and cost push theories. There are a number of causes of inflation which are related to expansion monetary or fiscal policy and this type of inflation can be referred as demand pull inflation (Mosayeb and Rahimi, 2009). Inflation may be caused by an increase in the quantity of money in circulation relative to the ability of the economy to supply. When there is an excess demand in the economy, producers raise their prices and gain higher profit margins. Possible causes of demand pull inflation are higher demand from government stimulus, monetary stimulus to the economy, faster economic growth in other countries and improved business confidence in the country.

The main sources of cost push inflation may be due to the cost of production, increasing wages, higher imports, raising taxes, budget deficit and fiscal deficit (Bashir, 2011). If there is 
an increase in the costs of firms, then firms will pass the cost to consumers. According to Sach and Larrain (1993) weather related factors (drought/flood) and failure in harvests would lead to price increase. Werasekara (1992), Rupananda (1994), Laryea (2001) and Rathnasiri (2009) find that inflation determinants belong to main demand pull and cost push inflation theories.

Phillip's curve suggested by A.W. Phillips in 1958, shows that wage inflation and unemployment are negatively related. This referred to as the trade-off between inflation and unemployment. Criticising Phillip's curve, Friedman (1968) and Phelps (1967) argued that this trade-off is not stable in the real world. According to them, the long-run Expectation Augmented Phillips Curve (EAP) was perfectly vertical at the natural rate of unemployment. Especially during the period of oil crisis, Phillip's curve seemed to breakdown all together. When oil price increases, inflation and unemployment increase accordingly. This is called as stagflation. The breakdown of the original Phillips curve can be explained in the EAP curve shown below in Eq. 1.

$$
\pi=\pi^{\mathrm{e}}-\beta 1\left(\mathrm{u}-\mathrm{u}^{*}\right)+\mathrm{E}
$$

Inflation $=$ Expected Inflation $-(B *$ Cyclical Unemployment $)+$ Supply Shock

When expected inflation increases, actual inflation also increases in any given unemployment level. Thus the modern Phillip's curve depends on expected inflation, the deviation of unemployment from the natural rate (cyclical unemployment) and supply shocks.

While the traditional Phillips curve is subject to considerable theoretical criticism, the New Keynesian Phillip's Curve (NKPC) relates inflation to the output gap and the cost-push effect influenced by expected inflation. At the cost of a lower output gap, policymakers could reduce inflation under the concept of the NKPC. Thus, the NKPC is used widely by academies to explain the effects of past and future inflation on current inflation. The standard model of the NKPC is in the following form;

$$
\pi_{t}=\beta E_{t} \pi_{t+1}+\alpha x_{t}+v_{t}
$$

Where $\pi_{\mathrm{t}}$ denotes inflation rate, $\beta$ is the discount factor, $\mathrm{E}_{\mathrm{t}}$ is expectations operator, $\mathrm{x}_{\mathrm{t}}$ is output gap and $\mathrm{v}_{\mathrm{t}}$ is exogenous shock to inflation process.

According to Gali and Gertler (1999), it is often difficult to detect a statistically significant effect of real activity on inflation using the structural formulation implied by the theory, when the measure of real activity is an output gap and failure to find a significant short-run link between real activity and inflation is unsettling for the story. There are some doubts on using NKPC to model inflation among researchers. Later, researchers have introduced a hybrid form of the backward-looking and the forward-looking Phillips curve (Mankiw, 2001). Hence, there are several theories explaining the causes of inflation; however, most of them are formulated on the basis of the aggregate demand (demand pull) and cost-push theories of inflation. 


\subsection{Empirical Evidence}

In addition to the theoretical literature reviewed previously, a number of empirical studies on inflation will be summarised in this section in order to examine the past experiences on inflation studies. Inflation could be the result of different sources simultaneously, hence, a single theory may not be sufficient and a combination of theories may be a good solution instead (Mosayeb and Rahimi, 2009).

The NKPC has frequently been used in the recent past in order to describe inflation dynamics. Gali and Gertler (1999) estimate the NKPC equation using the generalized method of moments (GMM) method. According to their findings, forward-looking behaviour is more important than backward-looking behaviour. Also, they suggest there is a robust and significant impact of marginal costs on inflation. Conversely backward looking price setting is not quantitatively important. Later, some researchers used proxies for marginal cost such as average unit labour cost. According to Woodford (2001), labour share is a much better measure of the true output gap for the purpose of explaining inflation variation. Nason and Smith (2008) who have estimated the NKPC for UK and Canada find that inflation tracks real unit labour costs rather than output gap measures. But some have argued that the output gap is the most appropriate variable in explaining inflation. However, the NKPC is a better method to estimate macroeconomic models and the monetary transmission mechanism.

Determinants of inflation have been examined by both developed and developing countries. It has been identified that there is a large number of factors in determining inflation. Cougani and Swagel (2001) investigate sources of inflation in 53 developing countries grouped by region (Africa, Asia, the Mediterranean and South America) and exchange rate regime (fixed or floating) for the period of 1964 to 1998. According to them, both demand pull and cost push factors affect inflation in developing countries. Their study shows that for African countries past realisations of inflation play a main role and accounted for two thirds of the variance of inflation. In contrast, South America's main determinant of inflation is fiscal variables. Their conclusion is faster money growth and exchange rate depreciation lead to higher inflation, while oil price hikes partly impact inflation.

In a similar vein, Osario and Unsal (2011) engaged in an empirical study to investigate inflation dynamics in Asia by presenting a two-step quantitative analysis of inflation dynamics. Those are Global VAR (GVAR) framework which is proposed by Pesaran, Schuermann and Weiner (2004) in order to estimate inflationary dynamics in the Asia and Pacific region and structural VAR for each country. Results show that inflation in China and India are mainly driven by domestic supply shocks. In Asia, commodity prices are especially a major source of inflation in demand side. Likewise, Moccero et al (2011) investigate the determinants of inflation in major OECD countries. They have divided OECD countries into four categories namely, USA, UK, Europe and Japan. They identify that output gap and unemployment related measures of the intensity of resource use are important factors of inflation determination in four economies during the recent past. 
Some of the studies find determinants of inflation from monetarist and structuralist perspectives. Callen and Chang (1999) examined the modelling and forecasting inflation in India. According to them, India followed monetarist and structuralist approaches for recent studies on inflation. Their models are based on the monetary approach and output gap and assessed the ability to forecast inflation development in India. They have used bivariate VAR estimation, series of granger causality and variance decompositions for their models. Results show that, money supply is the main determinant of inflation in India and foreign inflation has some effect on inflation in the short term. Thus, the output gap has some impact on inflation after one-quarter.

A VAR model is estimated for the period of 2004-2012 by Bhattacharya (2013), in order to examine major reasons for inflation in Vietnam, which experienced a high inflation level during the last several decades. Accordingly, nominal effective exchange rate, credit growth and real GDP are key drivers of inflation in the long run. Especially, there is a strong and significant relationship between credit growth and inflation in Vietnam. Interest rates of Vietnam do not have an impact on headline inflation in the short term or medium term which may reflect the weakness of the monetary policy in Vietnam. On the other hand, Laryea and Sumalia (2001) reveal that in the short run, output and monetary factors are the main sources of inflation in Tanzania and the exchange rate plays a main role in the long run. Proving the monetary theory on inflation, they find that monetary factors are more important in inflation determinants than real factors in Tanzania and conclude that the government should adopt a contractionary monetary and fiscal policy to control inflation.

A number of empirical studies have been conducted on the impact of government expenditure on inflation and theoretical and empirical evidence proves that prolonged fiscal expansions contribute to inflation and hence, there exists a positive long run relationship between government expenditure and inflation. Han and Mulligan (2008) carried out the study on three dimensions of data; cross country data was analysed for the relationship between inflation and size of government in long run for 80 countries, while time series data were used to identify the changes in total expenditure in disaggregate levels of defence and non-defence spending. In order to rectify the possible endogeneity problems in size of the government and non-defence expenditure, the government spending on social security to output ratio was used. Accordingly, they found a positive strong relationship between inflation and government's size during wartime. Furthermore, non-defence expenditure is negatively related with inflation and it is insignificant.

Conversely, Magazzino (2011) assessed the empirical evidence of the nexus between public expenditure and inflation for the Mediterranean countries and no clear evidence unveiled that the government spending caused price dynamics. Based on that study, he proved a longrun relationship between the growth of public expenditure and inflation, albeit only for Portugal. Furthermore, Magazzino found a short-run evidence of a unidirectional flow from expenditure to inflation for Cyprus, Malta and Spain, a unidirectional flow from inflation to public expenditure in France and a bidirectional flow for Italy. 


\subsection{Sri Lankan Context}

Several attempts can be observed in relation to the identification of determinants of inflation in Sri Lanka. These studies include Weerasekara (1992), Rupananda (1994), Bandara (1996), Colombage (2005), Gunasinghe (2007), Cooray (2008), Ratnasiri (2009) and Bandara (2011) among others. Most of these studies reveal the importance of both supply side and demand side factors in the determination of inflation in Sri Lanka.

Weerasekara (1992) reveals that the main source of inflation in Sri Lanka is money supply, using broad money supply and nominal exchange rate (rupee/US dollar) for the period of 1978 to 1992. Causality tests, variance decompositions and impulse response functions were performed on the VAR and the result of the model shows that an increase in money supply causes inflation. Exchange rate changes also caused inflation. According to the findings, there is bilateral causality between money supply and exchange rate changes.

Cooray (2008) finds a long run relationship between price level, real GNP, exchange rate and import prices. Two models, which are the known closed economy model based on the monetarist explanation modified to incorporate the time lags in the adjustment of prices in the money supply, and the open economy model that incorporates variables of import price index and foreign exchange rate were used. After the liberalisation of the economy, exchange rates and import prices became important factors on the general level of prices. According to findings, supply side factors are most important in the determination of inflation in Sri Lanka.

Ratnasiri (2009) examines the determinants of inflation in Sri Lanka for the period of 1980-2005 using a VAR based co-integration approach. This study finds that money supply growth and the increases in rice price are the most influencing factors for inflation in Sri Lanka in the short run as well as in the long run, while GDP growth and exchange rate depreciation is not important. Ratnasiri's study proves that both demand side and supply side factors affect inflation in Sri Lanka.

Rupananda (1994) highlights that after 1977, import prices and structural factors are more responsible for increasing inflation in Sri Lanka than monetary factors and indirect taxes marginally affected changes in price levels. Similarly; Bandara (1996) reveals that exchange rate and money supply have a large impact on inflation in the long run, while exchange rate depreciation significantly affects inflation in the short run. However, Colombage (2005) applies different econometric methods to ascertain the main determinants of inflation in Sri Lanka. It is shown that money supply plays a significant role in inflation in the short run as well as in the long run. Meanwhile, Gunasinghe (2007) examines the relationship between inflation and economic growth by using a co-integration analysis, generalised impulse response analysis and granger causality test. Results show that there is a negative relationship between inflation and economic growth. Further, Bandara (2011) investigates the determinants of inflation in Sri Lanka during the period of 1993-2008. Results of the model 
of inflation show that money supply, exchange rate and GDP helps in the determination of inflation in Sri Lanka.

In a similar vein, several empirical studies on inflation have emphasised on factors like political stability, credibility and reputation of government on inflation determinants. These kinds of factors vary from traditional inflation theories. Mozayed and Mohhamad (2009) find that the Iran-Iraq war had a positive significant effect on inflation during the investigated period. According to Rathnasiri (2009) and Swagel (2001), structural factors such as industrial and trading policies of government and weather conditions also influence inflation in developing countries.

Therefore, both demand side and supply side factors have been considered as influencing factors for inflation in theoretical and empirical literature. This review shows that most of the causes of inflation identified through empirical evidence are common for developing countries including Sri Lanka. In fact, the majority of the empirical studies in this area define inflation by using one of the following measures: the cost of living of the country, exchange rate, GDP, interest rates, out-put gap, money supply, budget deficit, climate changes, credit growth, political stability and import price etc.

Hence, this study would contribute to the available literature of inflation by focusing on the relationship between real, external, monetary and fiscal sectors on the economy and inflation.

\section{Methodology}

\subsection{The Model}

In order to determine the effect of variables on inflation, the following model, which was developed by Obstfeld and Rogoff (1996) and later modified by Ubide (1997) and Larea and Sumalia (2001), is applied. The model draws upon several theories relating to the inflation process and is set in a developing country. Ubide (1997) and Larea and Sumalia (2001) used this model for identifying inflation dynamics in two developing countries (Mozambique and Tanzania). Hence, the model is appropriate for analysing inflation dynamics in a developing country like Sri Lanka.

$$
\log P_{t}=\alpha\left(\log P_{t}^{T}\right)+(1-\alpha)\left(\log P_{t}^{N T}\right)
$$

Where, overall price level is $\mathrm{P}$ which is the weighted average of the price of tradable goods $\left(P^{T}\right)$ and non-tradable goods $\left(P^{N T}\right)$.

$$
0<\alpha<1
$$

The prices of tradable good are assumed to be determined in the world market. Prices of tradable goods depend on exchange rate $(e)$ and foreign prices $\left(P^{\gamma}\right)$. 


$$
\log P^{T}=\log e_{t}+\log P_{t}^{f}
$$

Therefore, the depreciation (appreciation) of the exchange rate or increase (decrease) in foreign prices will cause an increase (decrease) in the domestic price level in a small open economy like Sri Lanka. Thus, it is assumed that the price of non-tradable goods are mainly determined by money demand and money supply. So, real money supply $\left(M^{s} / P\right)$ equals real money demand $\left(m^{\alpha}\right)$ that can be represented by the money market equilibrium condition.

$$
\log P_{t}^{N T}=\beta\left(\log M_{t}^{S}-\log m_{t}^{d}\right)
$$

Demand for real money balances can be depicted as follows.

$$
\log m_{t}^{d}=\gamma_{o}\left(\log y_{t}-\gamma_{t} i_{t}\right)
$$

So demand for real money balances depend on real money income $(y)$ and interest rates $(i)$. Interest rate denotes opportunity cost of holding money.

We can obtain the equation of non-tradable goods by substituting Eq. 5 and 6 .

$$
\log P_{t}^{N T}=\beta\left(\log M_{t}^{S}-\gamma_{o} \log y_{t}+\gamma_{t} i_{t}\right)
$$

However the main model of this study slightly deviated from the model of Obstfeld and Rogoff (1996) which has been explained above. Crude oil prices have been considered as foreign prices in the model. In addition, to capture the government expenditure on inflation, recurrent expenditure has been included in the model. Long run equation of inflation is shown in Eq. 8.

$$
P_{t}=f\left(N E E R_{t}, E X_{t}, G D P_{t}, M S_{t}, O I L P_{t}, I N T_{t}\right)
$$

Where; the dependent variable is the inflation level (CCPI Index) and the independent variables are exchange rate (NEER), government expenditure (EX), gross domestic product (Real GDP), money supply (MS), crude oil price (OILP) and interest rate proxies by 91 - Treasury bill rate (INT). Hence, several shocks such as real, external, monetary and fiscal are captured in this study.

\subsection{Data and Estimation Method}

The CCPI is the official index of inflation in Sri Lanka. As there are several base years, both CCPI and GDP were converted into base years of 2006/2007 and 2002, respectively. NEER $^{5}$ represents the effective exchange rate in the country. Broad money supply $\left(M_{2}\right)$ is

\footnotetext{
5 NEER is an index consisting volume quotation i.e., US\$/RS (price of home currency in terms of foreign currency). The NEER of a given country $i$ is an index number expressed with a base of 100 (or 1) corresponding to its value at a given point in time $t$ (León-Ledesma, Miguel and Mihailov, 2014).
} 
used as the measure of money supply. Interest rate is the 91-days Treasury bill rate. Recurrent expenditure represents government expenditure of the country. All variables are expressed in logarithmic form, except interest rate. GDP and money supply are seasonally adjusted. To conduct this study, we have used data from the Central Bank of Sri Lanka (CBSL). On the basis of data availability, the model was estimated with data of a quarterly frequency for the period of 2000Q1 to 2013Q4. Broad money supply, GDP, government expenditure and oil price were in US dollar millions.

Variables used in the empirical analysis are defined in the following manner.

- $\quad$ CCPI $=$ Inflation $($ Base year $-2006 / 2007)$

- $\quad$ NEER = Nominal Effective Exchange Rate

- $\quad \mathrm{EX}=$ Government Recurrent Expenditure

- $\quad$ GDP $=$ Real Gross Domestic Product (Base year -2002)

- $\quad$ OILP $=$ Crude Oil (Brent)Price

- $\quad$ MS = Broad Money Supply

- $\quad$ INT $=$ Interest Rate Represented by 91-days Treasury Bill Rate

Descriptive statistics of data are given in Table 4.

Table 4: Descriptive Statistics

\begin{tabular}{lrrrrrrr}
\hline \hline & CCPI & NEER & EX & GDP & MS & OILP & INT \\
\hline Mean & 106.99 & 114.09 & $1,472.49$ & $5,229.38$ & $10,837.46$ & 65.50 & 11.30 \\
Median & 98.38 & 104.87 & $1,342.59$ & $5,119.58$ & $9,381.78$ & 63.75 & 10.10 \\
Maximum & 176.26 & 168.31 & $2,969.79$ & $6,818.39$ & $23,348.66$ & 139.30 & 21.30 \\
Minimun & 49.45 & 88.29 & 701.01 & $4,103.44$ & $4,518.17$ & 19.30 & 6.98 \\
Std. Dev. & 40.65 & 21.90 & 611.02 & 717.25 & $5,741.73$ & 33.96 & 3.95 \\
Skewness & 0.2070 & 1.0060 & 0.5943 & 0.0911 & 0.7003 & 0.2643 & 0.8757 \\
Kurtosis & 1.5747 & 2.9707 & 2.3444 & 1.5720 & 2.2111 & 1.7912 & 2.6388 \\
Jarque-Bera & 5.1397 & 9.4448 & 4.2565 & 4.8358 & 6.0295 & 4.0617 & 7.4622 \\
Observations & 56 & 56 & 56 & 56 & 56 & 56 & 56 \\
\hline Source: Author's Calculation & & & & & &
\end{tabular}

Table 4 shows that, on average CCPI and NEER were around 106.99 index points and 114.09 index points, respectively, and interest rates have increased by around 11.30 per cent per quarter. Money supply amounted to US dollars 10,837.46 million per quarter, while government expenditure amounted to US dollars 1,472.49 million. GDP was around US dollars 5,229.38 million in constant terms, while oil prices was US dollars 65.50 per barrel. 
By following the previous empirical literature (for example: Greenidge and DaCota, 2002; Odusunya and Atlanda, 2010; Bhashir, 2011 and Sahadudhhen, 2012), we mainly employ the co-integration method to examine the long run relationship between inflation and other variables namely money supply, GDP, government expenditure, exchange rate, oil prices and interest rates. Cointegration means that although many developments can cause permanent changes in the individual series, there is some long run equilibrium relation trying to keep the individual components together, representing a linear combination of the set of variables (Marmol and Velasco, 2004). When non-stationary variables move together over time it is described as a long run relationship between the variables. Short run disturbances will be adjusted towards the long run equilibrium. If two or more non-stationary series are having a long run relationship, they are said to be cointegrated.

The adjustment process in the short run towards the long run equilibrium is captured using the Vector Error Correction Mechanism (VECM). It permits consistent estimation of the cointegration space, providing short-run dynamics: movements in the short run which guides the economy towards the long-run equilibrium. The VECM specification restricts the long run behaviour of the endogenous variables to converge to their cointegrating relationships, while allowing a wide range of short run dynamics. The impulse response function will be used to examine the speed of recovery and adjustment path of inflation to an exogenous shock. The Granger causality test has been conducted in order to examine the causal relationship among variables. Variance decomposition tests are also employed in order to explain how much of a change in a variable is due to its own shock and how much is due to shocks from other variables.

\section{Empirical Analysis}

\subsection{Unit Root Tests}

In the first stage, this study performs the unit root test on each variable in order to examine the stationary or non-stationary level in a time series data set. If both stationary and nonstationary variables were included in an equation and estimated by Ordinary Least Squares (OLS), this will lead to a spurious regression. Therefore, it is important to differentiate between stationary and non-stationary variables. There are various alternative tests for testing whether a series is stationary. Commonly used tests are Augmented Dickey-Fuller (ADF) and Phillips-Perron (PP) tests.

This section conducts the unit root test using Augmented Dickey Fuller (ADF) test and Phillips-Perron (PP) test. A summary of the unit root test results are presented in Table 5 below. 
Table 5: Results of Unit Root Tests

\begin{tabular}{llcccc}
\hline \hline \multirow{2}{*}{ Variable } & Indicator & \multicolumn{2}{c}{ ADF } & \multicolumn{2}{c}{ PP } \\
\cline { 2 - 6 } & & Level & 1st Difference & Level & 1st Difference \\
\hline \multirow{2}{*}{ LNCCPI } & Statistic & -1.0486 & -5.1530 & -1.4288 & -5.0689 \\
& P-Value & 0.7294 & 0.0000 & 0.5617 & 0.0001 \\
\multirow{2}{*}{ LNEX } & Statistic & -0.6637 & -10.1036 & -1.6875 & -34.4973 \\
& P-Value & 0.8464 & 0.0000 & 0.4319 & 0.0001 \\
\multirow{2}{*}{ LNGDP } & Statistic & -0.2059 & -4.3492 & -1.4583 & -12.7548 \\
& P-Value & 0.9307 & 0.0000 & 0.5471 & 0.0000 \\
\multirow{2}{*}{ INT } & Statistic & -2.2083 & -4.7236 & -1.8663 & -7.5198 \\
& P-Value & 0.2058 & 0.0000 & 0.3445 & 0.0000 \\
\multirow{2}{*}{ LNOILP } & Statistic & -1.3743 & -7.0355 & -1.1267 & -8.3809 \\
& P-Value & 0.5883 & 0.0000 & 0.6991 & 0.0000 \\
& Statistic & -2.3088 & -6.4217 & -2.3131 & -6.4254 \\
& P-Value & 0.1729 & 0.0000 & 0.1716 & 0.0000 \\
\hline
\end{tabular}

At levels, the null hypothesis of unit root cannot be rejected for all the variables. Therefore the ADF and PP were conducted again for the first difference of each variable. The results show that the non-stationary hypothesis is rejected for the first difference of all the above variables. This indicates that each variable is integrated in order 1 . This concludes that each variable in the study can be made stationary by taking the first difference. In summary, since CCPI, MS, NEER, EX, GDP, OILP and INT are integrated in the same order (I(1)), these variables are suitable for the long run cointegration test.

\subsection{Preliminary Observations on the Relationships}

Several factors behind the volatility of inflation in Sri Lanka are discussed below. According to the classical theory, increases in money supply have positive effects on the inflation rate in a country. Without increasing production of goods and services in an economy, the increase in money supply leads demand pull inflation. Figure 3 below shows a positive relationship between inflation and money supply. When money supply increased, inflation also accelerated. The correlation between the two variables is 0.9653 . 
Figure 3: CCPI Index and Money Supply

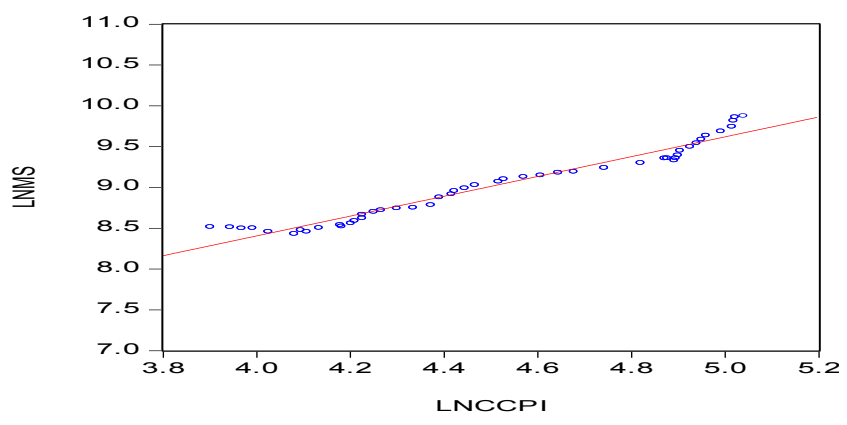

Source: Author's Calculation

If a developing country like Sri Lanka grows fast, productivity will increase in the tradable sector. It will result in increased wages and an increase in the prices of goods. Figure 4 below helps to get an idea of the time path of inflation and economic growth. It is clear that higher inflation is associated with higher growth in GDP. The correlation between inflation and GDP is 0.5787. Mallik and Chowdhury (2001) find evidence of a long-run positive relationship between GDP growth rate and inflation for four South Asian countries (Bangladesh, India, Pakistan and Sri Lanka).

Figure 4: CCPI Index and GDP

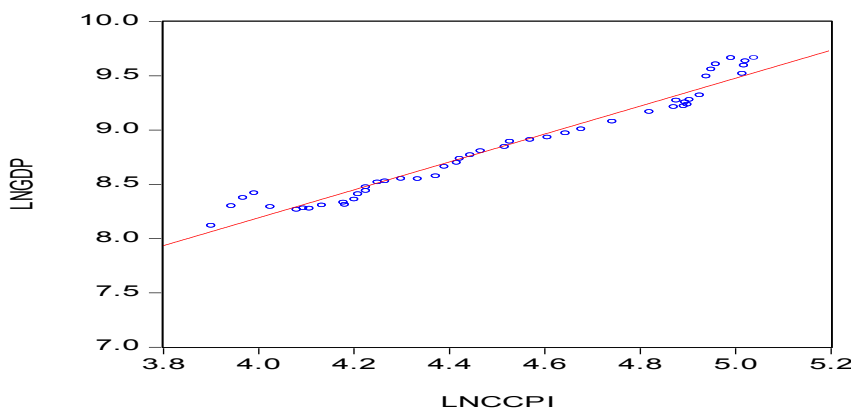

Source: Author's Calculation

The depreciation of the exchange rate also affects the prices (domestic currency units) of tradable goods and indirectly affects the general price level. Exchange rate depreciation raises the domestic price of imported goods, thereby fuelling domestic inflation (Almounsor, 2010). Figure 5 below illustrates the relationship between inflation and the exchange rate 
(NEER) and the correlation coefficient between the two variables are -0.8654 . Bhattacharya (2013) supports this view in his study where he states that the key driver of inflation in the short-run is the movement in the nominal effective exchange rate in Vietnam.

Figure 5: CCPI Index and Exchange Rate

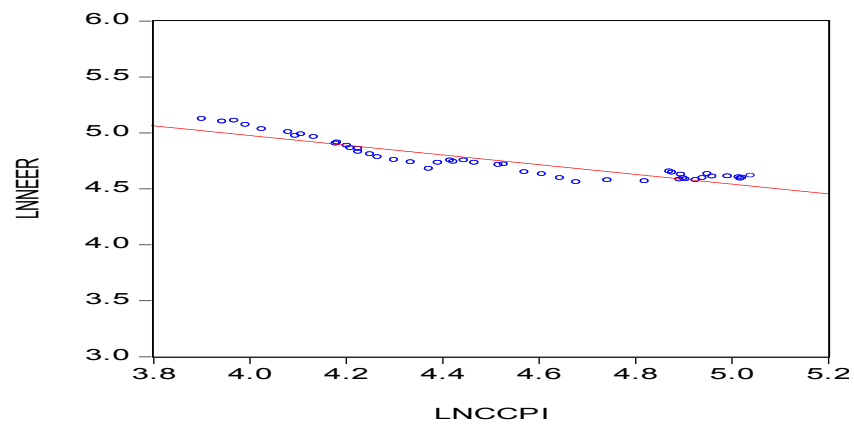

Source: Author's Calculation

Interest rate is another variable which is highly correlated with inflation. If domestic interest rates are kept low, then it would increase inflation. Studies of Kihangire and Mugyenyi (2005) and Greenidge and DaCosta (2002) find that a decreased interest rate influence increases inflation. Figure 6 below represents the fluctuations of inflation and Treasury bill rates (91 days). There is a negative relationship (-0.3049) between interest rates and inflation.

Figure 6: CCPI Index and Interest Rates

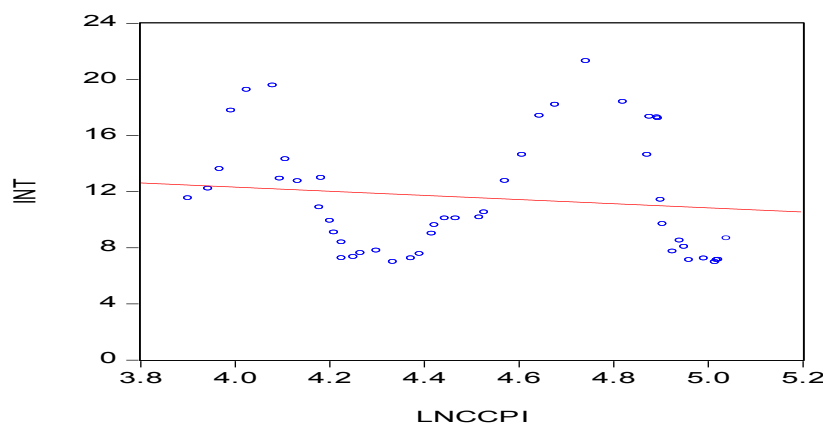

Source: Author's Calculation 
Ezrim et al (2008) and Bashir et al (2011) find that government expenditure and inflation are positively related with each other. Government expenditure may result in increasing the price level, reflecting its fiscal dominance, which could be usually seen in the developing countries. When government spends more, it would result in pressures on prices through the expansion of aggregate demand. Figure 7 below illustrates a positive relationship between inflation and government expenditure and the correlation coefficient between the two variables are 0.9215 .

Figure 7: CCPI Index and Government Expenditure

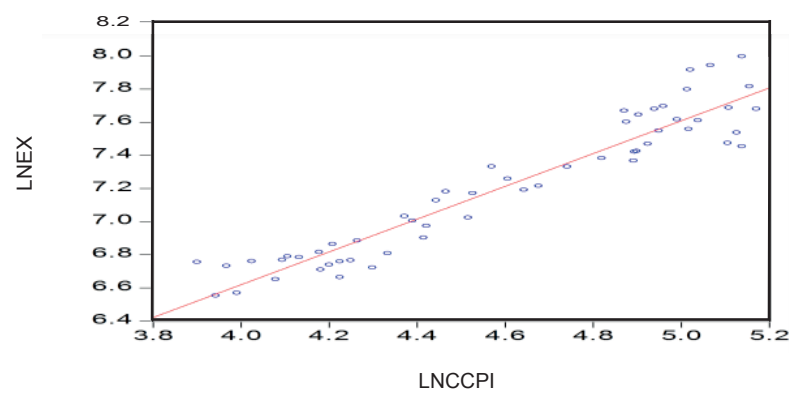

Source: Author's Calculation

A developing country like Sri Lanka mainly depends on imported goods such as crude oil, wheat, milk etc. Thus, the volatility of international oil prices especially the increasing domestic price level in the country. Therefore, changes in oil prices are closely related with inflation. According to Goyal (2011), South Asian countries oil prices and other external shocks gives a useful opportunity to better understand the structure of inflation of these economies. Figure 8 below shows a positive relationship between inflation and oil prices. The correlation between the two variables is 0.9326 .

Figure 8: CCPI Index and Oil Price

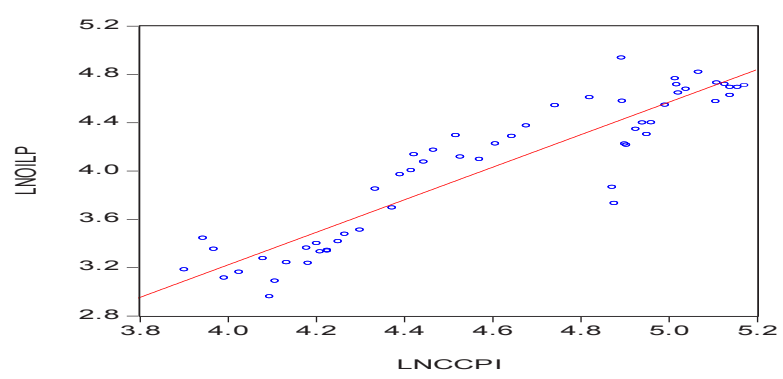

Source: Author's Calculation 
Accordingly, money supply, GDP, oil prices and government expenditure positively correlated with inflation, while increasing inflation has shown a sharp depreciation in the exchange rate (NEER). The interest rate has fluctuated considerably along with inflation.

\subsection{Co-integration Analysis (Long Run Analysis)}

This study uses the cointegration analysis developed by Johansen and Juselius (1990) to estimate the long run relationship among variables. The results of the Johansen cointegration are reported in Appendix 1. To test the null hypothesis $r=0$ against the general alternative $r=1,2,3,4,5$ or $6, \lambda_{\text {trace }}$ statistics should be used. Since $\lambda_{\text {trace }}$ statistics of $r=0$ is 143.4142 , and it is larger than the critical value of 125.6154 , the null hypothesis is rejected at the 5 per cent significance level, so that the variables are cointegrated using this test. Similar to the $\lambda_{\text {trace }}$ statistic, the $\lambda_{\max }$ statistic of $r=0$ is 51.2222 , and it is larger than the critical value of 46.2314 , the null hypothesis is rejected at the 5 per cent significance level. So the $\lambda_{\text {trace }}$ and $\lambda_{\max }$ statistics confirm that there is one co-integration vector.

Several significant findings have been discovered from this analysis. The result of the normalised cointegration coefficients are presented in table 6 below.

Table 6: Normalised Cointegration Coefficients

\begin{tabular}{lccccccc}
\hline \hline & LNCCPI & LNNEER & LNEX & LNGDP & LNMS & LNOILP & INT \\
\hline$\beta$ Coefficient & 1.0000 & 0.6423 & -0.5498 & -0.6800 & -0.2365 & -0.1183 & 0.0437 \\
Std. Error & & 0.1192 & 0.0527 & 3.0011 & 0.0712 & 0.0362 & 0.0202 \\
t-Statistic & $5.3881^{*}$ & $-10.4406^{*}$ & -0.2266 & $-3.3222^{*}$ & $-3.2649 *$ & $2.1697^{*}$ \\
\hline
\end{tabular}

* Significant at $5 \%$ level

Source: Author's Calculation

It is expected that money supply, government expenditure, oil price and GDP exert a positive influence on inflation rates in Sri Lanka and that interest rates and exchange rates negatively relate to the inflationary process. According to the normalised co-integration equation of long run regression; all variables carry the expected signs during the review period. Therefore, the resultant long run model for inflation determinants for Sri Lanka can be specified as follows.

$$
\begin{aligned}
& \text { LNCCPI }(-1)=1.56311-0.642 \operatorname{LNNEER~}(-1)+0.549 \operatorname{LNEX}(-1)+0.680 \operatorname{LNGDP}(-1) \\
& +0.236 \operatorname{LNMS}(-1)+0.118 \operatorname{LNOILP}(-1)-0.043 \operatorname{INT}(-1)
\end{aligned}
$$


Eq. 9 above shows the long term dependence of inflation on the variables included in the model. It has been found that, the appreciation of the exchange rate has a significant negative impact on inflation in the long run. The appreciation of exchange rate by 1 per cent is associated with the decrease in inflation by 0.64 per cent. Wimalasuriya (2008) found that during the period 2000-2005, a 1 per cent depreciation of the exchange rate induced a 0.3 per cent increase in retail consumer prices in the long run in Sri Lanka. The same relationship has been observed by Greenide and DaCosta (2002) and Almounsor (2010). According to Cooray (2008) and Bandara (1996) the exchange rate is a central factor in influencing Sri Lankan inflation. The depreciation in the exchange rate can cause a rise in import prices and it might cause cost push inflation. In addition, the exchange rate affects inflation through supply side. Hence the exchange rate is one of the main macroeconomic fundamentals that affect inflation in a small open economy like Sri Lanka. Exchange rate policies have a role to play in stabilising inflation (Kihangire and Mugyenyi, 2005).

The long run inflation function indicated that government expenditure has a positive impact on inflation. When government expenditure is increased by 1 per cent, the inflation rate also increases by 0.55 per cent in the long run. When government spending is increased, it would result in pressures on prices through the expansion in aggregate demand. Also, the internal conflict that prevailed in Sri Lanka for around three decades made a significant volatility in inflation and further, the high defence expenditure was a major burden on government spending. The positive impact of government expenditure on inflation may have been strengthened by defence expenditure among other components of government expenditure. For example, Magazzino (2011) reveals that there is a long-run relationship between public expenditure/GDP growth and inflation for Portugal.

In the same manner, economic growth caused by increased aggregate demand leads to an acceleration in inflation in the economy. When the GDP increases by 1 per cent, the inflation rate will increase by 0.68 per cent. Bandara (2011), Callen and Chang (1999), Bhattacharya (2013) and Greenide and DaCosta (2002) have found that GDP is a key driver of inflation in the long run through the demand side of the economy.

This shows that 1 per cent increase in money supply will increase inflation by 0.24 per cent. Since all the variables are expressed in logarithm, the estimated coefficients are interpreted as elasticities. Price elasticity with respect to money supply is 0.24 . Devapriya and Ichihashi (2012) found that during the period 1950-2010, a 1 per cent change in growth rate of money supply will induce 0.18 positive change in the inflation rate in Sri Lanka. Due to high money supply, investments will increase and more employment opportunities will generate. As a result aggregate demand will increase and ultimately there will be an increase in domestic price levels due to higher demand. Accordingly, money supply affects inflation through the demand side. Weerasekara (1992), Laryea and Sumaila (2001) Ratnasiri (2009), Odusunya and Atanda (2010), Bandara (2011), Bashir (2011), Sahdudhhen (2012) and Arif and Ali (2012) also found that money supply has a long run significant impact on inflation. 
However, results of long run analysis found that the exchange rate has a higher impact on inflation than money supply. These improvements have included greater clarity and transparency with respect to monetary objectives and instruments as well as greater exchange rate flexibility (Osorio and Unsal, 2011). And the contribution of monetary shocks to inflation may diminish over time, perhaps reflecting the improvements in monetary frameworks in the country.

In the same manner, oil prices indicate a positive impact on inflation. When oil prices increase by 1 per cent, the inflation rate increases by 0.12 per cent in the country. Due to higher oil prices, expenditure on imports will increase and investments will decline accordingly. As a result, the production of goods and services will reduce and it will impact the acceleration of inflation. According to Kihangire and Mugyenyi (2005), higher oil prices affect oil importing economies in two ways and could lead to an increase in firms' production costs and reduce profits.

Moreover, inflation and interest rates are correlated with each other. Studies by Greenidge and Da Costa (2002) and Kihangire and Mugyenyi (2005) find that the decrease in interest rates influence increased inflation. The empirical results show that the interest rate has a marginal impact on inflation. Accordingly, the increase of 1 per cent in interest rates leads to around 0.04 per cent decrease in inflation. When the interest rate increases more than the inflation rate, it leads to increase or constant savings and decreased expenditure on goods and services. As a result of decrease in money demand, the money supply also decreases. Thus, there will be a downward trend in domestic prices.

\subsection{Vector Error Correction Estimates (Short Run Analysis)}

Given that the above mentioned variables are cointegrated, the next step is to estimate the Vector Error Correction Estimates (VECM). A summary of the VECM results are presented in Table 7 below.

Each error correction equation includes the error correction coefficient $(\alpha)$, error correction term lagged once $\left(u_{t-1}\right)$, current and first lag values of variables of the first difference of each variable. All regressors in the ECM models are predetermined and are one quarter ahead predicted values and they are true ex-ante forecasts. First row includes error correction coefficients. 
Table 7: Summary Results of VECM

\begin{tabular}{cccccccc}
\hline \hline & $\begin{array}{c}\mathbf{D} \\
(\text { LNCCPI) }\end{array}$ & $\begin{array}{c}\text { D } \\
(\text { LNNEER) }\end{array}$ & $\begin{array}{c}\text { D } \\
(\text { LNEX) }\end{array}$ & $\begin{array}{c}\text { D } \\
(\text { LNGDP) }\end{array}$ & $\begin{array}{c}\text { D } \\
\text { (LNMS) }\end{array}$ & $\begin{array}{c}\text { D } \\
\text { (LNOILP) }\end{array}$ & $\begin{array}{c}\text { D } \\
\text { (INT) }\end{array}$ \\
\hline $\begin{array}{c}\boldsymbol{\alpha} \\
\text { Coefficient }\end{array}$ & -0.0640 & 0.3434 & 0.8635 & 0.0098 & 0.0839 & -0.1303 & -0.0868 \\
\hline Std. Error & 0.0843 & 0.1449 & 0.4973 & 0.0112 & 0.1469 & 0.8774 & 0.8912 \\
\hline t-Statistic & -0.7594 & $2.3696^{*}$ & 1.7365 & 0.8777 & 0.5712 & -0.1485 & -0.9742 \\
\hline
\end{tabular}

* Significant at $5 \%$ level

Source: Author's Calculation

The magnitude of each error correction term shows how quickly the deviation of each variable from the long run equilibrium is corrected gradually towards the equilibrium level through a series of partial short run adjustments. Short run dynamics show in lag $1(-1)$. $T$ statistics of $(-1)$ coefficients of these variables explain that these variables are weakly exogenous. However, the error correction term has a negative sign as expected. The error correction model of the inflation rate is -0.0640 . The interpretation of this error correction term is that once the inflation rate deviates from the equilibrium value determined by the fundamentals, the adjustment rate of the inflation rate is 6.40 per cent on quarterly basis. This can be considered as quite a slow rate of adjustment.

\subsection{Impulse Response Analysis}

Impulse response functions trace the impact of a shock emanating from endogenous variables to other variables (Almousor, 2010). In this section the study investigates how an exogenous shock to a variable affects other variables in the model through an analysis of their impulse response functions. The results of impulse response function analysis are given in Figure 9 below. 


\section{Figure 9: Results of Impulse Response Analysis}

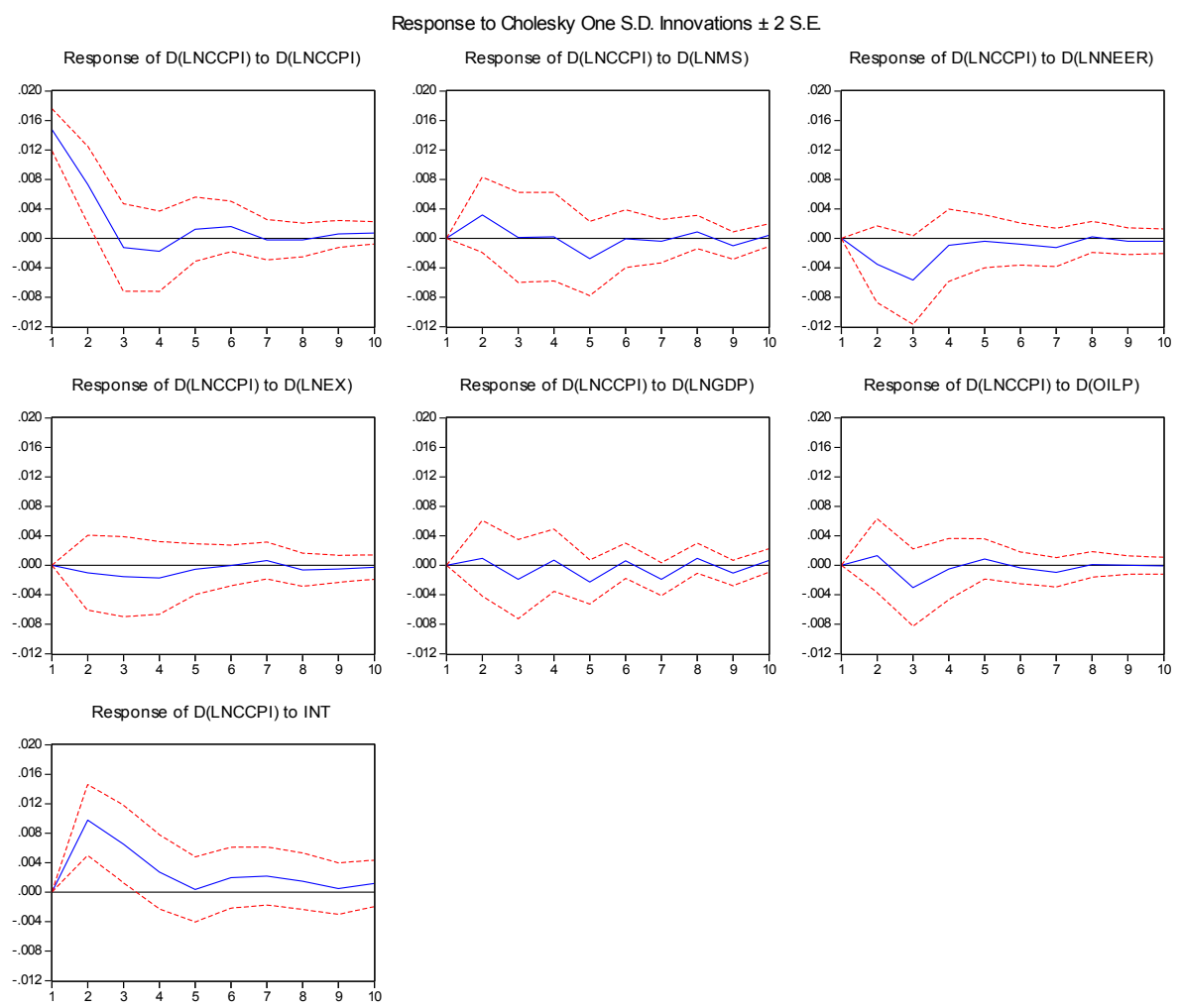

Source: Author's Calculation

In impulse response results, we find that a positive shock of CCPI to the inflation has a positive effect on inflation until 3 periods and then stabilize gradually. It proved that domestic price shocks lead to more inflation. The response of inflation to money supply shows that money supply will have an expansionary effect until 2 quarters and stabilizes thereafter. The appreciation of exchange rate has a significant negative impact on inflation over the medium term horizon of 8 quarters. Accordingly, the inflation response to appreciation on the exchange rate is immediate. Almounsor (2010) also found that the nominal appreciation on the exchange rate reduces inflation. Government expenditure has a small negative impact on inflation until 6 quarters and gradually stabilises. However, it is not in line with what is expected and observed. A positive shock to the GDP will have an expansionary effect on inflation in 2 periods and a contractionary effect over the medium term. Shock to oil prices has positive impact on inflation until 2 periods. On the other hand, 
the decrease in interest rates has a positive impact on inflation until 5 quarters and gradually stabilises thereafter. The result of interest rates on the Granger causality test is consistent with results of Ratnasiri (2009) who has done a VAR based analysis. The impulse responses suggest that external shocks (i. e., exchange rate and oil prices) have an increasing impact on inflation. Also, domestic shocks associated with money supply, interest rates and GDP have an increasing impact on inflation over short term.

\subsection{Variance Decomposition}

The results of the variance decomposition of the CCPI are given in Appendix 2 . The variance decomposition of the CCPI gives the changes in the growth in CCPI attributable to each of the other variables included in the model as well as itself. After 5 periods, the CCPI is explained more than 65 per cent by itself and interest rates and oil prices contribute around 19 per cent and 7 per cent respectively. Hence, the variance decomposition of inflation indicates that short run dynamics in inflation are explained mostly by its own fluctuations, followed by interest rates and oil prices. After 10 periods, about 50 per cent of the variance in the inflation is explained by inflation itself. About 20 per cent variance in inflation is from interest rates; about 15 per cent and 7 per cent variances are from government expenditure and oil prices. Other variables contribute very little to explaining inflation after 10 periods. This result shows that inflation itself, government expenditure and interest rates accounted for over 85 per cent variability in the inflation after 10 periods.

\subsection{Diagnostic Tests}

Several diagnostic test namely serial correlation test, heteroskedasticity test and normality tests were performed. A detailed description of diagnostic tests is shown in Appendix 3. First, serial correlation tests were conducted. Serial correlation determines how well the past values of a variable predict the future value of the same variable. At 5 per cent significance level, it fails to reject the hypothesis that there is no serial correlation issue in variables. Secondly, heteroskedasticity tests were performed. Since the p value of Chi-Square (0.1455) is not less than 0.05 , it does not reject $\mathrm{H} 0$, which means that there is no heteroaskedasticity. The final diagnostic test was done by conducting the normality test. According to the normality test, since p-value is 0.0700 which is greater than 0.05 , we do not reject $\mathrm{H} 0$ at 5 per cent level of significance and it can be concluded that residual are normally distributed. 


\section{Conclusions and Policy Implications}

This paper reviews the impact on key macroeconomic determinants of the inflation in Sri Lanka covering the period of 2000-2013 for quarterly data. As such, this study would contribute to the available literature of inflation by focusing on the relationship of inflation with real, external, monetary and fiscal sectors of the economy. In particular, existing studies on inflation in Sri Lanka do not consider the fiscal effect on inflation in detail. Thus, most of the research in this area have not considered oil price changes on inflation in Sri Lanka. Moreover, under significant structural changes of the economy after the end of the internal conflict and the persistence of current low inflation situation in Sri Lanka, identifying the determinants of inflation is vital for policy makers in their effort in maintaining price stability.

Depending on the necessity, tests and models such as unit roots, cointegration analyses, VECM, impulse response and variance decomposition tests were employed. According to the results of the research, several determinants of Sri Lanka's inflation have been identified.

The study revealed that both long run and short run factors influence inflation in Sri Lanka. Based on the results of the model, exchange rate, money supply, GDP, government expenditure, oil prices and interest rate explain inflation in Sri Lanka. This study found that increase in the money supply will increase domestic price level in the country. Due to higher money supply, investments will increase and more employment opportunities will be generated. As a result, the aggregate demand will increase and ultimately there will be an increase in domestic price level due to higher demand. Accordingly, money supply affects inflation through demand side. Further, there is a strong positive link between inflation and the exchange rate. The exchange rate is one of the main macroeconomic fundamentals that affect inflation in a small open economy like Sri Lanka.

Government expenditure also affects inflation through demand side. Higher expenditure increases the aggregate demand of goods and services. This would result in higher domestic price levels. In the same manner, GDP has a positive impact on inflation. Consequently, it has shown that there is a positive relationship between international oil prices and inflation. Thus empirical findings indicate that the decreasing interest rates have a positive effect on inflation in Sri Lanka. Therefore, it has proved that in the long run, both supply side and demand side factors namely, money supply, exchange rate, government expenditure, oil price GDP and interest rates play important roles in the inflation process in Sri Lanka during the investigated period.

In the short run, the error correction term has negative sign as expected and there is quite a low rate of adjustment. Impulse responses suggest that key drivers of inflation in the short term are exchange rate, money supply, interest rates, oil prices and GDP. Results of Variance decomposition results revealed that inflation itself, government expenditure and interest rates accounted for over 85 per cent variability in the inflation after 10 periods. Therefore, it has been proved that both demand pull and cost push factors affect inflation in Sri Lanka as shown by Ratnasiri (2009). 
According to the above results, a number of policy implications can be derived. First small open economies like Sri Lanka experience demand pull inflation due to the impact of expansionary monetary and fiscal policies. As highlighted by Almousor (2010), over the medium term, close coordination between monetary policy and fiscal policy is important to alleviate inflationary pressures. Policies include wage control, monetary policy (reduction in money supply) and fiscal policy (increase in personal income tax and reduction in government expenditure) and increase in output of goods and services will help in controlling inflation in Sri Lanka.

As GDP is a main factor affecting inflation in Sri Lanka, the results of this study emphasise the need to create a stable macroeconomic policy environment to promote growth in an effort to maintain price stability. Also, policy makers need to give their attention to inflationgrowth relationship which is a relatively under-explored area. Attempts to reduce inflation to a very low level (or zero) are likely to adversely affect economic growth (Mallik and Chowdhrury, 2001). Hence, the challenge for policymakers is to find a growth rate which is consistent with a stable inflation rate in Sri Lanka. Although a country needs inflation for growth, significantly high growth rates may accelerate the inflation rate as found by Bruno and Easterly (1998).

Keynesian style demand side policies alone would not be enough to reduce inflation. Supply side factors like exchange rate and oil prices are important determinants in inflation. Greater volatility of exchange rate will result in higher volatility in inflation. This study has found that the exchange rate has a significant impact on inflation in Sri Lanka. Hence, exchange rate is one of the main macroeconomic fundamentals that affect inflation in a small open economy like Sri Lanka. As Sri Lanka is a net importer of crude oil, volatility on international oil prices has a positive impact on inflation. Nguyen et al (2012) explain that external shocks such as oil prices are difficult to avoid in a small open economy. Accordingly exchange rate movements and international oil prices have both short-run and long-run effects on the inflation. The impact of increased foreign prices such as crude oil could be off-set to some extent by managing the exchange rate at an appropriate level. Finally, higher government expenditure would lead to higher inflation in a country. Government expenditure affects through demand side, as with high expenditure, aggregate demand of goods and services will increase and it would lead to higher overall prices in the economy (Bashir, 2011). Hence targeting a low inflation level together with tight fiscal policy would help to reduce inflation level in the country.

There are a few limitations in this study. Temporary shocks that raise domestic prices such as weather related factors or other commodity shocks have not been addressed in this paper. These factors may be dominant inflation triggers. Hence, expanding the analysis by including more variables such as weather related factors, credit growth, political stability etc. may lead to more robust results. Moreover, the use of alternative methods such as SVAR and FAVAR (for example: Osairo and Unsal, 2011) would help to deepen understanding of dynamics of inflation in Sri Lanka. Future research can consider the above directions in order to derive firm policy conclusions. 


\section{References}

Arif, K. M. and Ali, M. M, 'Determinants of inflation in Bangladesh, an empirical investigation', Journal of Economics and Sustainable Development, Vol 3, No, 12, (2012).

Almousor, A. 'Inflation dynamics in Yemen: An empirical analysis', IMF Working paper, WP/10/144, (2010).

Bhattacharya, R, 'Inflation dynamics and monetary policy transmission in Vietnam and Emerging Asia', IMF Working Paper, WP/13/155, (2013).

Bandara, A. 'Short-run dynamics of Inflation: Do monetary and exchange rate policies matter?-An empirical investigation for Sri Lanka', Staff Studies, Central Bank of Sri Lanka, (1996).

Bandara, R. 'The determinants of inflation in Sri Lanka: An application of the vector auto regression model', South Asia Economic Journal, 12 (2), (2011), 271-286.

Bashir, F. 'Determinants of inflation in Pakistan: An Econometric analysis using Johansen co-integration approach', Australian Journal of Business and Management Research, Vol. 1 No 5, (2011), 71-82.

Bruno, M, 'Does high inflation really lower growth', Finance and Development, Vol. 32, 35-38, (1995).

Bruno, M. and Easterly, W, Inflation crisis and long-run growth', Journal of Monetary Economics, Vol. 41, 3-26, (1998).

Callen, T. and Chang, D, 'Modelling and forecasting inflation in India ', IMF Working paper, WP/99/119, (1996).

Caraballo, A, 'Inflation and supply shocks in Spain: A regional approach ', 46th ERSA Congress, University of Seville, (2006).

Cooray, A. V, 'A model of Inflation for Sri Lanka', Review of Applied Economics, 4 (1), (2008), 35-44.

Colombage, S. S, 'Determinants of inflation in Sri Lanka: An econometric analysis', Journal of Humanities, Social Sciences and Education, (2005).

Cougani, P. and Swagel, P, 'Sources of inflation in developing countries ', IMF Working papers, WP/01/198, (2001).

Central Bank of Sri Lanka, 'Annual Reports (Various Issues)'.

Central Bank of Sri Lanka, 'Economic progress of independent Sri Lanka ' (1998).

De. Grauwe, P. and Polan, M, 'Is Inflation Always and Everywhere a Monetary Phenomenon? ', International Macroeconomics, No. 2841, (2001). 
Devapriya, K. P. N. T. N. and Ichihashi, M, 'How does budget deficit affect inflation in Sri Lanka?' IDEC Discussion Paper, (2012).

DaCosta, D. and Greenidge, K, 'Determinants of inflation in selected Caribbean countries', 29th Annual Review Seminar, (2002).

Ezirim, C. Muoghalu, M. I. and Elike, U , 'Inflation versus public expenditure growth in the US: An empirical investigation', North American Journal of Finance and Banking Research, Vol. 2, (2008).

Friedman, M, 'The Role of Monetary Policy', American Economic Review, Vol. 58, 1-17, (1968).

Frisch, H, 'Inflation theory 1963-1975: A second g generation survey', Journal of Economic Literature, Vol. 15, (1977), 1289-1317.

Gali, J. and Gertler, M, 'Inflation Dynamics: A structural econometric analysis', Journal of Monetary Economics, Vol. 44(2), (1999).

Greenidge, K. and DaCosta, D, 'Determinants of inflation in selected Caribbean countries', Business, Finance \& Economics in Emerging Economies, Vol 4 No. 2, (2006).

Gunasinghe, C, 'Inflation and economic growth: A case study of Sri Lanka', Proceeding of the fourth academic sessions 2007, University of Rubuna, (2007).

Goyal, A , 'Inflationary pressures in South Asia', MPDD working papers, WP/11/14, (2011).

Han, $\mathrm{H}$ and Mulligan, C. B. , 'Inflation and the size of government', Federal Reserve Bank of St. Louis Review, May/June 2008, 90(3, Part 2), (2008), 245-267.

Hossain, T, 'An economic analysis of the determinants of inflation in Bangladesh', International journal of social sciences, Vol.11, No 1, (2012).

Juselius, K, The cointegrated VAR model- methodology and applications, Oxford university press, (2005).

Kihangire, D. and Mugyenyi, A, 'Is inflation always and everywhere a non-monetary phenomenon? Evidence from Uganda', Bank of Uganda, Working paper, WP/05/05, (2005).

Kusper, $\mathrm{H}$, 'The role of external and country specific factors in Hungarian inflation developments', Maayar Nemzeti Bank, WP 2012/05, (2012).

León-Ledesma, Miguel and Mihailov A., 'Advanced International Macroeconomics and Finance', Oxford University Press, (2014).

Lim, C. H. and Papi, L, 'An econometric analysis of the determinants of the inflation in Turkey', IMF Working Paper, WP/97/170, (1997). 
Laryea, S .A. and Sumaila, U. R, 'Determinants of inflation Tanzania', Institute of Development Studies and Human Rights, WP 2001: 12, (2001).

Mallik, G. and Chowdhury, A, 'Inflation and economic growth-evidence from four South Asian Countries', Asia-Pacific Development Journal, Vol 8, No 1, (2001), 123-135.

Mankiw, N. G, 'The inexorable and mysterious trade-off between inflation and unemployment', The Economic Journal, III (May), (2001), C45-C61.

Mankiw, N. G, Macroeconomics, Fifth Edition edn (New York: Worth Publisher, 2003).

Magazzino, C, 'The nexus between public expenditure and inflation in the Mediterranean countries', MPRA paper, No. 28493, (2011).

Moccero, D. Watanabe, S. and Cournes, B, 'What drives inflation in the major OECD economies?' Economic Department, Working papers, 854, (2011).

Mosayeb, P. and Rahimi, M, 'Sources of inflation in Iran: An application of the ADRL approach', International Journal of Applied econometrics and Quantitative Studies, Vol. 6-1, (2009).

Nason, M. and Smith, W, 'The new Keynesian Philips curve: Lessons from single equation econometric estimation', Federal Reserve Bank of Richmond Economic Quarterly, Vol. 94. 361-395, (2008).

Nguyen, H. Covoli, T. and Wilson, J. K, 'The determinants of inflation in Vietnam', Asian Economic Bulletin, Vol. 29, No 1, (2012), 1-14.

Obstfeld, M. and Rogoff, K, 'Foundations of open economy macroeconomics', MIT Press, (1996).

Odusanya, I. A. and Atanda, A. A. , 'Analysis of inflation and its determinants in Nigeria', Pakistan Journal of Social Sciences, Vol. 7, No. 2.97-100, (2010).

Osario, C and Unsal, D. F, 'Inflation dynamics in Asia: Causes, changes and spill overs from China', IMF Working paper, WP/11/257, (2011).

Phelps, E.S, 'Phillips curves, expectations of inflation and optimal unemployment over time', Economica, Vol. 34, 283-299, (1958).

Ratnasiri, H. P. G. S. , 'The main determinants of inflation in Sri Lanka, A VAR based analysis', Staff Studies of CBSL, Vol. 39 , (2009).

Rupananda, W, 'Econometric model for inflation in Sri Lanka', Economic Review, People's Bank, Vol. 20, (1994).

Sachs, J. D. and Larraín B. F, 'Macroeconomics in the global economy', Englewood Cliffs, New Jersey: Prentice Hall, (1993). 
Sahadudhhen, I, 'A co-integration and error correction approach to the determinants of inflation in India', International journal of Economics and Research, Vol. 3, No. 1 (2012), (2012), 105-112.

Loungani, P, and Swagel, Phillips, 'Sources of inflation in developing Countries', IMF working paper, WP/01/198, (2001).

Tayeh, S. N. A. and Mustafa, M. H, 'The determinants of public expenditures in Jordan', International Journal of Business and Social Science, 2(8), (2011), 45-49.

Ubide, A, 'Determinants of inflation in Mozambique', IMF Working Paper, WP/97/145, (1997).

Weerasekara, Y. M. W. B, 'Inflation in Sri Lanka. A causality analysis', The South East Asian Central Banks, Staff Papers, No 46, (1992).

Wimalasuriya, S. M, 'Exchange rate pass-through: To what extent do prices changes in Sri Lanka', Staff Studies of CBSL, Vol. 37 Number 1 \& 2, (1998).

Woodford, M, 'Inflation stabilization and welfare', NBER Working Paper, No. 8071, (2001).

Zang, X, 'China's inflation: Demand -pull or cost -push?' Asian Economic Papers, Vol 11.3, (2012). 
Appendix 1

Johansen Test for Cointegration

\begin{tabular}{|c|c|c|c|c|}
\hline \multirow{2}{*}{$\begin{array}{l}\text { Hypothesized No. of } \\
\text { CE(s) }\end{array}$} & \multicolumn{2}{|c|}{ Test Statistics } & \multicolumn{2}{|c|}{0.05 Critical Values } \\
\hline & Trace Statistic & $\begin{array}{c}\text { Max-Eigen } \\
\text { Statistic }\end{array}$ & Trace & Max-Eigen \\
\hline None * & 143.4142 & 51.22223 & 125.6154 & 46.23142 \\
\hline At most 1 & 92.19198 & 34.12467 & 95.75366 & 40.07757 \\
\hline At most 2 & 58.06732 & 24.38630 & 69.81889 & 33.87687 \\
\hline At most 3 & 33.68102 & 20.69609 & 47.85613 & 27.58434 \\
\hline At most 4 & 12.98493 & 7.823024 & 29.79707 & 21.13162 \\
\hline At most 5 & 5.161909 & 5.151201 & 15.49471 & 14.26460 \\
\hline At most 6 & 0.010708 & 0.010708 & 3.841466 & 3.841466 \\
\hline
\end{tabular}

Appendix 2

Results of Variance Decomposition

\begin{tabular}{ccccccccc}
\hline \hline Period & S.E. & LNCCPI & LNNEER & LNEX & LNGDP & LNMS & LNOILP & INT \\
\hline $\mathbf{1}$ & 0.015526 & 100.0000 & 0.000000 & 0.000000 & 0.000000 & 0.000000 & 0.000000 & 0.000000 \\
$\mathbf{2}$ & 0.028879 & 92.34880 & 0.010468 & 1.110741 & 1.663374 & 0.027925 & 0.181348 & 4.657339 \\
$\mathbf{3}$ & 0.039214 & 79.89355 & 0.664895 & 2.710622 & 1.388850 & 0.015391 & 3.878408 & 11.44829 \\
$\mathbf{4}$ & 0.047689 & 69.78947 & 0.863180 & 4.285550 & 1.863999 & 0.126407 & 6.021076 & 17.05032 \\
$\mathbf{5}$ & 0.054317 & 64.69302 & 1.259049 & 5.950861 & 2.021374 & 0.136882 & 6.593631 & 19.34519 \\
$\mathbf{6}$ & 0.060325 & 59.84908 & 1.647806 & 8.419882 & 2.956293 & 0.153606 & 7.009425 & 19.96391 \\
$\mathbf{7}$ & 0.065099 & 55.67246 & 2.162705 & 11.01335 & 3.417938 & 0.139577 & 7.268367 & 20.32560 \\
$\mathbf{8}$ & 0.068693 & 52.68285 & 2.481547 & 12.85160 & 4.046059 & 0.180549 & 7.195480 & 20.56191 \\
$\mathbf{9}$ & 0.071345 & 50.92168 & 2.935552 & 14.04401 & 4.232004 & 0.207482 & 7.124490 & 20.53478 \\
$\mathbf{1 0}$ & 0.073769 & 49.53084 & 3.251606 & 15.12357 & 4.484202 & 0.240756 & 7.066291 & 20.30274 \\
\hline
\end{tabular}

Source: Author's Calculation 
Appendix 3

Results of Diagnostics Tests

(1) Serial Correlation LM Test

\begin{tabular}{ccc}
\hline \hline Lags & LM-Stat & Probability \\
\hline $\mathbf{1}$ & 57.02089 & 0.2015 \\
$\mathbf{2}$ & 75.66529 & 0.1086 \\
$\mathbf{3}$ & 43.04227 & 0.7123 \\
$\mathbf{4}$ & 61.75365 & 0.1044 \\
$\mathbf{5}$ & 55.08815 & 0.2553 \\
$\mathbf{6}$ & 59.18262 & 0.1512 \\
$\mathbf{7}$ & 56.75604 & 0.2084 \\
$\mathbf{8}$ & 53.06927 & 0.3202 \\
$\mathbf{9}$ & 53.20709 & 0.3155 \\
$\mathbf{1 0}$ & 38.18978 & 0.8677 \\
\hline
\end{tabular}

(2) Heteroskedasticity Test

\begin{tabular}{ccc}
\hline \hline Chi-Sq & DF & Probability \\
\hline $\mathbf{8 8 3 . 3 3 7 7}$ & 840 & 0.1455 \\
\hline
\end{tabular}

(3) Normality Test

\begin{tabular}{cccc}
\hline \hline Component & Jarque-Bera & $\mathbf{d f}$ & Prob. \\
\hline $\mathbf{1}$ & 2.939448 & 2 & 0.2300 \\
$\mathbf{2}$ & 2.008116 & 2 & 0.3664 \\
$\mathbf{3}$ & 4.062167 & 2 & 0.1312 \\
$\mathbf{4}$ & 6.205006 & 2 & 0.0449 \\
$\mathbf{5}$ & 3.273492 & 2 & 0.1946 \\
$\mathbf{6}$ & 1.361198 & 2 & 0.5063 \\
Joint & 19.84943 & 12 & 0.0700 \\
\hline
\end{tabular}

